\title{
- READING MACBETH THROUGH CONCEPTUAL METAPHOR ANALYSIS: PATH AND CONTAINER SOURCE DOMAINS
}

\author{
MIRKA ĆIROVIĆ 1 \\ Faculty of Philology \\ University of Belgrade \\ Serbia
}

Rad za cilj ima čitanje Šekspirove tragedije Makbet pomoću analize pojmovnih metafora u metaforičkim izrazima koji se temelje na izvornim domenima PUTANJA i SADRŽATELJ. Iz pomenutog dramskog dela biće izdvojeni najznačajniji metaforički jezički izrazi koji se odlikuju složenošću filozofske misli i pesničkom lepotom, a od čijeg suštinskog poimanja ne zavisi samo razumevanje pojedinačnih stihova, već $i$ dramskog dela u celini. Činjenica da u drami Makbet preovlađuju izvorni domeni PUTANJA (path) i SADRŽATELJ (container) svakako nije slučajna. Ovakav dominanatan obrazac pojmovne metafore jeste mehanizam koji dramski pisac svesno koristi i razrađuje kako bi na željeni način izgradio likove, zaplet, i kako bi na čitalačku i pozorišnu publiku ostavio određeni utisak. Analiza pojmovne metafore omogućava da se prevaziđe nivo reči i da se zaroni u dublji smisao dela, onaj koji se tiče promišljanja o apstraktnom i konceptualizacije nadčulnog. Budući da Šekspirova veličina leži upravo u njegovoj veštini da ono što je teško izrecivo predstavi u stihu, analiza pojmovne metafore i metaforičkih jezičkih izraza u njegovim delima nameće se kao važan predmet naučnog istraživanja.

Ključne reči: pojmovna metafora, metaforički jezički izrazi, Makbet, putanja, sadržatelj, izvorni domen.

1 Kontakt podaci (Email): mirkacirovic@gmail.com 


\section{INTRODUCTION: CONCEPTUAL METAPHOR THEORY IN LITERATURE}

Roman Jacobson pointed out that a linguist negligent of the poetic functions of language represents an equally flagrant anachronism as a literary scholar oblivious of linguistic aspects of texts that they study. Exploring the relationship between linguistics and literature cannot be avoided (Carter and Simpson 1995). Conceptual metaphor is the link which binds language, thought, and comprehension. For most people, metaphor is a device that poets and writers use as a means to achieve extraordinary language, and it is usually perceived as a matter of words alone. On the contrary, metaphor does not only exist in poetry.

It is omnipresent in daily lives, and it is not a matter of language only, but of thought and action as well (Lakoff and Johnson 1980: 3). Ever since Lakoff and Johnson published their epochal work Metaphors we Live by, literary scholars have become concerned with how individual authors use metaphor in their work, with how they develop metaphorical patterns as part of their perception and style. In recent years, literary scholars are becoming more and more influenced by conceptual metaphor theory, and they have started to treat conceptual metaphor as a representation of an author's world view. Margaret Freeman, for example, argued that Emily Dickinson's poetry is dominated by LIFE IS A VOYAGE IN SPACE conceptual metaphor, which was out of line with dominant metaphors at the time normally used as basis for conceptualizing life (Semino and Steen 2008: 239). As another example of metaphor analysis approach to literature, Crisp argued that the usage of image metaphors was the main characteristic of Imagist poetry that we recognize in Ezra Pound and T. E. Hulme (Crisp 2003). Lodge described the transition of Virginia Woolf's novels towards experimentation and modernism as a transition from a metonymic to a metaphoric style (Semino and Steen 2008: 239). Freeman noticed that Shakespeare's Macbeth is pervaded by metaphorical linguistic expressions that draw on the source domains PATHS and CONTAINERS. It is his work that gives ground for this research.

PATH and CONTAINER based conceptual metaphors build the dramatic language of Macbeth from the beginning to the end. They are also central in giving structure to characters and the plot. We are physical beings set off from the rest of the world by the surface of our skin, and in this sense, each of us is a container. Bounded objects, whether humans or non-humans, can be described in terms of the quality and quantity of the substance that they contain (Lakoff and Johnson 1989: 29-30). Metaphors based on CONTAINER as the source domain will be investigated with the aim of demonstrating that they consistently reveal the truth about human nature through the characters of Macbeth and Lady Macbeth. On the other hand, PATHS as source domains contain three main elements: a starting point, a terminal point, and a vector that traces a sequence of locationsand events(Freeman 1995:692).PATHasa source domain in metaphorsisolated from the play puts emphasis on Macbeth and Lady Macbeth's ambition to become king and queen of Scotland, and it gives prominence to the imperial theme. In order to focus on a qualitative and an in-depth discussion about human characters, human nature, and purposes in life that are governed by ambition, the data of this research paper will focus on metaphorical linguistic expressions that are most interesting and most representative of CONTAINERS and PATHS as source domains. By analysing conceptual 
metaphors deriving from metaphorical linguistic expressions, we will not only provide better understanding of the lines of the play and the play itself, but we will also try to answer some substantial questions about humanity that Shakespeare himself was preoccupied with. What is man who is ready to commit bloody and damnable crimes in order to achieve his ambition made of? Where does ruthless ambition take us in life, and in what ways does it determine our actions?

\title{
2. PATH AS A SOURCE DOMAIN IN MACBETH
}

Bradley wrote about Macbeth who "strides from crime to crime though his soul never ceases to produce shapes of terror" (Bradley 1919:353). Hazlitt noted that Macbeth is "blindly rushing forward on the objects of his ambition and revenge" (Hazlitt 1939: 14). Lowe talked about the "highway" of Macbeth's progress, and Watson said that at the end of the play the tragic hero finds himself "on a liner course into winter" (Freeman 1995: 690). Eagleton notices that in Macbeth's case, there is "always another step to be taken" before he can secure his throne and his position as king (Freeman 1995: 690). The views of critics who wrote on Macbeth are representative of the general tendency to describe the play and the tragic hero in terms of journeys, paths, and steps:

\author{
thou art so far before \\ That swiftest wing of recompense is slow \\ To overtake thee. \\ (Macbeth I, IV, 16-18)
}

King Duncan conceptualizes Macbeth's progress by relying on PATH as the source domain. The brave warrior has advanced rapidly on the path of success so Duncan must come up with a "flying" reward to catch up with Macbeth's achievements. CAREERS ARE PATHS conceptual metaphor is a frequent way of thinking about goals, achievements, and purposes. Movement and direction are seen as basic experiences that we rely on to grasp the abstract. The idea of a direction involves going forward, backward, up and down. Direction involves movement and change (Kövecses 2010: 49). Macbeth understands his career as an upward path. In order to reach the top, he must go through different stages of the journey, with Glamis and Cawdor being two stops on his way to ultimate destination, which is the absolute authority of a monarch. Once Glamis and Cawdor are "behind", Macbeth can focus on what is ahead.

TIME IS A MOVING OBJECT metaphor explains that time may run or fly, which gives time the quality of motion and direction. The future is facing towards us, and the past is behind our back. This is how we get expressions ahead of us, look forward, before us and such (Lakoff and Johnson 1980: 42, 43). There is another metaphor that helps us conceptualize time TIME IS STATIONARY AND WE MOVE THROUGH IT. We sometimes say that we move through years or decades; we may go further back in time, and we may approach the end of the year. In these cases, we move and time stands still. The two metaphors strike us as not being consistent, but they still fit together because they give prominence to different aspects of time, helping us to understand this concept better and from different perspectives: 
Come what come may,

Time and the hour runs through the roughest day.

(Macbeth I, III, 152-153)

In the metaphorical linguistic expression above, day is perceived as path, while time is the trajectory (Freeman 1995: 702). Time travels fast, it "runs" according to Macbeth's perception, which means that he must act quickly in order to keep up with the time and not be run over by it. This race with time, and the idea that he should be faster than historical events and circumstances, enable Macbeth to leave a certain impression on readers. This play is shorter than Shakespeare's other tragedies, but time passes quickly, and numerous events take place so that the text does not appear short, but intense:

\author{
I have no spur \\ To prick the sides of my intent, but only \\ Vaulting ambition, which o'erleaps itself \\ And falls on th' other. \\ (Macbeth I, VII, 25-58)
}

Macbeth is considering committing murder of a legitimate king, but ideas of right and wrong give rise to moments of indecision. While his actions are slowed down by moral codes, patriarchal and basic human principles, Macbeth conceptualizes his intention as a horse. Horse is a much faster traveler than a man, and a rider can spur his horse in order to speed up the progress on the path that leads towards the ultimate goal. The tragic hero gives himself boost to persist on his path of succeeding to the throne:

\title{
The Prince of Cumberland! that is a step \\ On which I must fall down, or else o'erleap, \\ For in my way it lies.
}

(Macbeth I, IV, 48-50)

When Duncan proclaims Malcom the heir to the throne, Macbeth faces an impediment on his upward path of success. Another conceptual metaphor emerges here - CAREER DIFFICULTIES ARE OBSTACLES. Macbeth understands that his ascension to the throne in legal and legitimate ways is impossible, so he is considering taking allor-nothing leap. The concept of succession is also perceived through the source domain of PATH (Freeman 1995: 700, 702). When Duncan names Malcom Prince of Cumberland, Macbeth thinks in terms of an obstacle so steep that it reminds him of a staircase. He considers murdering Banquo because he is painfully aware of the fact that his throne is barren, while Banquo's line of kings "will stretch out to th' crack of doom" Succession and changes on the throne involve the passage of time. If Macbeth wants to come to the throne soon, he has to leap over the order of succession, take shortcuts, and progress quickly. Succession assumes time and space, in which Macbeth kills the king and everyone who might endanger his absolute power: 
To-morrow, and to-morrow, and to-morrow, Creeps in this petty pace from day to day

To the last syllable of recorded time, And all our yesterdays have lighted fools

The way to dusty death.

(Macbeth V, V 19-22)

Macbeth's trajectory is now described as creeping, and his pace is "petty". He can no longer jump over obstacles, wade through rivers, or spur his horse. His progress is slow, and his movement reminds of an old man. At this stage, Macbeth measures time in terms of yesterday and today. "Our yesterdays" illuminate and define our paths, so that our final points are either expected or clearly visible. The lines also mark the collapse of time, the lost significance of the present, past, and future. LIFE IS LIGHT and LIFE IS A JOURNEY metaphor are combined here. This is especially obvious if we take into consideration metaphorical linguistic expression "Out, out, brief candle!" The brief distance between Macbeth's current position on the path and his death is marked by proximity. This brevity is also represented in the vertical distance from candle's wick to the terminal point of its base (Freeman 1995: 702, 705). Macbeth is an implied observer of his path. When he talks about "to-morrow", and when he mentions "the way to the dusty death", he refers to his inevitable death. By mentioning "our yesterdays", Macbeth casts a look behind at days gone by in order to pose a question about our past defining our future:

I have lived long enough: my way of life

Is fall'n into the sear, the yellow leaf;

And that which should accompany old age,

As honour, love, obedience, troops of friends,

I must not look to have;

(Macbeth V, III, 24-27)

Macbeth conceptualizes his life as a journey along a specific path that includes a change of scenery from a fertile and watered landscape towards arid and "sere" one. The path and landscapes that we go through on the way towards our goals are the fluid of life. LIFETIME IS A YEAR metaphor is responsible for our understanding of different sceneries where autumn is perceived as the late stage of life that precedes death. This perception enables the elegiac comprehension of Macbeth's solitude and lack of companions at the very end of his life. On his path, on a heath near Forres, Macbeth is intercepted by the Three Witches. The influence of their prophecies on Macbeth is great, but agency belongs to the tragic hero only. There is no evidence in the play that Shakespeare meant to assign Macbeth's choices to supernatural agents. It is blatantly clear that he is not under spell, and that witches do not bond him in any way:

If chance will have me king, why, chance may crown me, Without my stir.

(Macbeth I, III, 147-8) 
We will proceed no further in this business:

He hath honour'd me of late; and I have bought

Golden opinions from all sorts of people,

Which would be worn now in their newest gloss,

Not cast aside so soon.

(Macbeth I, VII, 32-35)

When we think about the metaphor PURPOSES ARE DESTINATIONS, another subordinate metaphor emerges from depths of the given lines - CHOICES IN LIFE ARE CROSSROADS (Lakoff and Turner 1989: 3). It seems that all Shakespeare's tragic heroes stand at the crossroads at one point, and the wrong choices that they make are responsible for their tragic downfalls. In accordance with this tendency, Macbeth has doubts whether to commit a damnable crime, break many laws of man and God, and jump over the line of succession. Becoming a king would fulfil his ambition to seize the absolute power on earth, which is why his ultimate goal seems worth it. At the same time, he is unwilling to cast away his good name, his reputation of a brave warrior, and virtuous lord. Apparently, there are two perceptions of events in life that cause dilemma. EVENTS ARE ACTIONS metaphor implies that agency is connected to the occurrence of an event (Lakoff and Turner 1989: 37).

On the other hand, EVENTS ARE STATES metaphor allows for a certain passivity, where things may happen to us without our "stir". Macbeth eventually resolves his dilemma by deciding to shape his own destiny and the destiny of so many others according to his dangerous ambition and dark desires.

\section{CONTAINER AS A SOURCE DOMAIN IN MACBETH}

The Three Witches' caldron is a container in which they stir a toxic stew, which is one of the most memorable images in the play. Macbeth's castle in Inverness is a container as well. It contained the body natural and body politic of a legitimate king, and it was supposed to have an exterior protection purpose. Macbeth's violation of his ancient duties as king's host, cousin, and subject turns the castle in Inverness into a locus of annihilation of basic human and God's laws. Macbeth's regicidal dagger that is conjured in the castle penetrates a series of moral and physical containers that are supposed to protect the king (Freeman 1995: 697). The container of Macbeth's castle assumes the existence of other containers, one of them being the room in which Duncan sleeps. Lady Macbeth conceptualizes herself and her husband as containers. In her view, Macbeth is a vessel filled with "milk of human kindness", and she finds the makeup of his body directly responsible for the reluctance to commit a crime, and seize the throne swiftly and efficiently by force and violence:

yet do I fear thy nature;

It is too full o' the milk of human kindness

To catch the nearest way:

(Macbeth I, V, 3-5) 
Lady Macbeth expresses her concern over her husband's resolution and readiness to embrace villainy and seize the throne by regicide when she refers to "milk of human kindness". Her husband not only contains "milk of human kindness" in his body, but he is also full of it. Lady Macbeth links Macbeth to feminine tenderness, because of sympathy and remorse that he is prone to. In her invocation of dark powers, she proclaims that she would like to be able to "pour" her "spirits" into her husband's ears. That way, Lady Macbeth could lull his overpowering conscience, and fill up Macbeth's body with humours that have taken over her being - thick blood and gall. Gall is related to choler since it is associated with liver. The choleric person in the time of Renaissance was described as angry, impatient, and full of heat. Choleric characters are seen as appealing for dramatic purposes because they give rise to personages such as Lady Macbeth, and subsequently Macbeth. Shakespeare, his characters, and his audience understood that type, balance or disbalance of fluids in the body explained people's behaviours, their mood, and readiness to act. This is why Lady Macbeth expresses the desire to drain her husband's body of "milk of human kindness", and fill it up with humours suitable for undertaking swift and powerful actions that include executing bloody tasks:

Come, you spirits

That tend on mortal thoughts, unsex me here,

And fill me from the crown to the toe top-full

Of direst cruelty. Make thick my blood.

Stop up the access and passage to remorse,

That no compunctious visitings of nature

Shake my fell purpose, nor keep peace between

The effect and it! Come to my woman's breasts,

And take my milk for gall, you murd'ring ministers,

Wherever in your sightless substances

You wait on nature's mischief.

(Macbeth I, V, 30-40)

The altered humour makeup of Lady Macbeth's body that we see as a container will result in her woman's body being perceived as anti-nourishment. She rejects motherhood in full awareness of the fact that it means giving up on humanity, feelings of sympathy, and every form of kindness whatsoever. Her body will then represent a container of poison, malice, and cruelty that is metaphorized as another liquid necessary for the foul deed. Along with invocating darkness from hell, Lady Macbeth also summons the process of thickening that will prevent any change in her creating of anti-nature. If we think about BODY IS A CONTAINER FOR EMOTIONS, it means that the more fluid there is in a container, the greater the insanity of the feeling. When the amount of liquid that represents a certain emotion comes above the threshold, the feeling comes into existence, but it is still far from intensive. This is the situation that we monitor in Macbeth's case as he begins to acknowledge his dark desires and as he considers murdering the king in order to fulfil his ambition. Similarly, when the amount of the liquid fills the container from its bottom to the very brim, this indicates a high level of emotion. This is where we recognize Lady Macbeth from the very beginning 
of the play (Kövecses 1986: 83). She wants to be filled "from the crown to the toe tip" with cruelty and substances that propel mischievous behaviour. The fact that she uses the word "crown" instead of the word head shows that she has started to perceive the crown as an inherent part of her body.

MIND IS A CONTAINER metaphor is the base for Macbeth's statement that his mind is "full of scorpions". Macbeth plans to murder Banquo and Fleance because he believes that this will relieve his anxiety, insomnia, and paranoia. However, when Fleance escapes, Macbeth finds his mind more confined than earlier. The fact that Macbeth's brain has scorpions inside it helps us conceptualize the tragic hero's current state of being. He cannot sleep. He is alone and restless. His mood changes swiftly and suddenly. There is fever in his blood, which urges him to constantly do something in order to relieve his pain and discomfort. Scorpions are associated with night and poison. If we see them as swarming in Macbeth's mind, then evil and ruthlessness that characterize the tragic hero may be seen as venomous and disgusting. The content of Macbeth's mind is similar to the Three Witches' cauldron, where loathsome nocturnal creatures, amphibians and insects mainly, are cooked, stirred and boiled to create horror and fear.

AIR IS A CONTAINER conceptual metaphor is responsible for hallucinatory effects of the play. The dagger which Macbeth sees with the handle towards his murderous hands is contained in the air, and is made of air. Perceiving air as a container in which supernatural images and images of the mind are conjured strengthens the impression that hallucinations and paranoia leave on readers. The Three Witches disappear into the air, and it seems to Banquo and Macbeth that this element contains things noncorporal. The Three Witches, and the way in which they disappear, make air resemble water because they look like being made of bubbles. The importance of the supernatural can hardly be exaggerated. The Three Witches are symbolic representations of the unconscious and half-conscious, which exist in man. They are exterior projections of Macbeth's and Lady Macbeth's deepest desires and dark ambitions:

Most sacrilegious murder hath broke ope

The Lord's anointed temple, and stole thence

The life o' the building!

(Macbeth II, III, 41-43)

Macduff understands the murderer as a burglar who has broken into the sacred temple of king's body natural. The temple is "anointed" because it contains the body politic of the monarch. The item stolen from the temple is precious, and it translates to king's soul and his life. According to Freeman, the loot that the burglar has removed from the interior of the container is the spirit that gives life to Duncan, and consequently to his kingdom.

The concept of a container maps the importance that the Holy Spirit has for a sacred temple and a religious community to the significance of Duncan's life and soul for his kingdom and his subjects.

The spring, the head, the fountain of your blood

Is stopp'd; the very source of it is stopp'd.

(Macbeth II, III, 76-77) 
Macbeth conceptualizes Duncan's body as a spring and as a fountain, which under pressure gives a steady flow to fluid that sustains life, just as water does. While Duncan is connected to the concept of nourishment, Macbeth and Lady Macbeth are often depicted through images of anti-nourishment.

\section{CONCLUSION}

Conceptual metaphors function as the skeleton of a text. They represent the foundation for building complex ideas, meanings, and views. Understanding Macbeth in terms of PATH and CONTAINER source domains has been present in the literary critics and scholars circles for decades. Thanks to conceptual metaphors that draw on these source domains, we manage to understand not only the language of this play, but also its characters, settings and general atmosphere. Macbeth's entire life, career, his rise and fall are built upon conceptual metaphors with PATH as the source domain. In order to travel the path that he has chosen for himself, Macbeth has to run, ride, jump, climb, and swim, which is why there is an overall impression of quick action in the play. All the agility that the tragic hero is endowed with through the play finishes in a petty pace and a tone of profound philosophical understanding that the things we did yesterday shape what will become of us tomorrow. Macbeth and Lady Macbeth display changes in their characters as they follow their ambition to seize the absolute power in Scotland. A hesitant, ambitious man turns into a pitiless tyrant, while his instigator becomes a mentally ill woman ridden with remorse. Human character, human nature and their alteration in the given circumstances are central themes introduced into the play through the source domain of CONTAINER. This source domain gives the play its hallucinatory effects, and it enables us to comprehend emotions, life, death, and the makeup of things. PATH and CONTAINER metaphors are not only dominant source domains in the play, but they also interact with one another and with other conceptual metaphors to illustrate a four-dimensional and comprehensive fall of human nature.

\section{REFERENCES}

Bradley, A. C. 1914. Shakespearean Tragedy. London: Macmillan.

Carter, R. \& P. Simpson. 1995. Language, Discourse and Literature. London: Routledge. Crisp, P. 1996. Imagism's Metaphor: A Test Case. Language and Literature 5, 79-92.

Freeman, D. 1995. Catching the nearest way: Macbeth and cognitive metaphor. Journal of Pragmatics 6, 689-708.

Hazlitt, W. 1939. Characters of Shakespeare's Plays. London: Oxford University Press.

Kövecses, Z. 2010. Metaphor: A practical introduction. New York: Oxford University Press. Lakoff, G. \& M. Turner. 1980. More than Cool Reason: A Field Guide to Poetic Metaphor. Chicago: The University of Chicago Press

Lakoff, G. \& M. Johnson. 1980. Metaphors We Live By. Chicago: The University of Chicago Press.

Semino, E. \& G. Steen. 2008. Metaphor in Literature. In R. W. Gibbs (ed.) The Cambridge Handbook of Metaphor and Thought. Cambridge: Cambridge University Press, 232-246. 


\section{SUMMARY}

\section{READING MACBETH THROUGH CONCEPTUAL METAPHOR ANALYSIS: PATH AND CONTAINER SOURCE DOMAINS}

This paper applies the theory of conceptual metaphor to Shakespeare's play Macbeth with the aim of understanding the characters, structure of the plot, individual lines, and the text as a whole in a more profound, in-depth manner. At the beginning, there is a brief reference to literary scholars' growing interest in how individual authors develop metaphorical patterns which are revelatory of meanings that go beyond the level of language, into thought and comprehension of the abstract. Donald C. Freeman noticed that critical tradition has understood and wrote about Shakespeare's Macbeth in terms of PATH and CONTAINER source domains. Following in his footsteps, this paper focuses on the metaphorical expressions from the play that are built upon PATH and CONTAINER conceptual metaphors, and proves that Shakespeare intensely structures our understanding of human nature and purposes governed by sombre desires of the unconscious through these exact modes of cognition. The analysis presents Macbeth's blood-thirsty career in the form of a contained path, while the hallucinatory effects of the play and the questions of human nature are mainly visualized as containers. Besides showing that PATH and CONTAINER are dominant conceptual metaphors in the play, they are also seen in interaction with one another, and as intertwined with other complementary conceptual metaphors to build the philosophical, psychological, and cognitive basis of the play.

KEYWORDS: conceptual metaphor, metaphorical linguistic expressions, Macbeth, PATH, CONTAINER, source domain.

ARTICLE INFO:

Original research article

Received: October 152019

Revised: November 62019

Accepted: December 252019 